\title{
Vitamin D and bone health
}

\author{
Susan Lanham-New \\ From Musculoskeletal Health in the 21st Century \\ Guildford, UK. 30 June - 1 July 2015
}

Throughout the life-cycle, the skeleton requires optimum development and maintenance of its integrity to prevent fracture. Bones break because the loads placed upon them exceed the ability of the bone to absorb the energy involved. It is now estimated that $1: 3$ women and 1:12 men over the age of 55 years will suffer from osteoporosis in their lifetime and in the UK, at a cost in excess of $£ 1.7$ billion per annum to the exchequer. The pathogenesis of osteoporosis is multi-factorial. Both the development of peak bone mass and the rate of bone loss are determined by key endogenous and exogenous factors. Calcium supplements appear to be effective in reducing bone loss in late menopausal women ( $>5$ years post-menopause), particularly in those with low habitual calcium intake $(<400 \mathrm{mg} / \mathrm{d})$. In younger postmenopausal women, who are not vitamin $\mathrm{D}$ deficient, vitamin $\mathrm{D}$ supplementation has little effect on BMD. However, vitamin D and calcium supplementation studies have been shown to reduce fracture rates in the institutionalized elderly but there remains controversy as to whether supplementation is effective in reducing fracture in free-living populations. Re-defining vitamin $D$ requirements in the UK is urgently needed since there is evidence of extensive hypovitaminosis $\mathrm{D}$ in the UK. Low vitamin D status is associated with an increased risk of falling and a variety of other health outcomes and is an area that requires urgent attention. The role of other micronutrients on bone remains to be fully defined, although there are promising data in the literature for a clear link between vitamin $\mathrm{K}$ nutrition, dietary protein and dietary alkali on skeletal integrity including fracture reduction.

Published: 1 December 2015

Department of Nutritional Sciences, Faculty of Health and Medical Sciences, University of Surrey, Guildford, GU2 7XH, UK C BHoMed Central

(0) 2015 Lanham-New This is an Open Access article distributed under the terms of the Creative Commons Attribution License (http:// creativecommons.org/licenses/by/4.0), which permits unrestricted use, distribution, and reproduction in any medium, provided the original work is properly cited. The Creative Commons Public Domain Dedication waiver (http://creativecommons.org/publicdomain/ zero/1.0/) applies to the data made available in this article, unless otherwise stated.
doi:10.1186/1471-2474-16-S1-S16

Cite this article as: Lanham-New: Vitamin $\mathrm{D}$ and bone health. BMC

Musculoskeletal Disorders 2015 16(Suppl 1):S16. and take full advantage of:

- Convenient online submission

- Thorough peer review

- No space constraints or color figure charges

- Immediate publication on acceptance

- Inclusion in PubMed, CAS, Scopus and Google Scholar

- Research which is freely available for redistribution 